Amaltea. Revista de mitocrítica

ISSN-e: 1989-1709

http://dx.doi.org/10.5209/AMAL.54283

\title{
Gendering Globalized Flows in Bertrand Bonello’s Tiresia
}

\author{
Christina Dokou ${ }^{1}$
}

Recibido: 10 de noviembre de 2016 / Aceptado: 25 de abril de 2017 / Publicado: 15 de octubre de 2017

\begin{abstract}
Presented as the conciliatory voice of wisdom, Teiresias, the blind theban seer who had been both man and woman, exemplifies how transcending gender can lead to a questioning of normative, victimizing cultural mandates within the polis. This gender-bending acquires further applications in the 2003 film, Tiresia, about the myth-informed travails of a transsexual brazilian illegal immigrant prostitute in france. The film daringly deconstructs the dividing lines within contemporary globalized flows: immigrants vs. citizens, men vs. women, dogma vs. humanity. The performative gender of "tiresia" exposes but also exacerbates the effects of cultural violence, yet also intimates peaceful alternatives.

Keywords: Teiresias; Tiresia; Bonello; gender; immigration; transsexuality; androgyny; globalization; Greek myth; performativity.
\end{abstract}

\section{[es] Corrientes globalizadas de la ideología de género en Tiresia de Bertrand Bonello}

Resumen. Voz conciliadora de la sabiduría, Tiresias, el adivino tebano que había sido tanto hombre como mujer, ejemplifica cómo trascender el género puede llevar a un cuestionamiento de la norma, victimizando los mandatos culturales dentro de la polis. Esta mezcla de géneros adquiere nuevas aplicaciones en la película Tiresia (2003), sobre los esfuerzos mito-informados de una prostituta transexual brasileña que vive como inmigrante ilegal en Francia. La película desconstruye atrevidamente las líneas divisorias dentro de las corrientes globalizadas contemporáneas: inmigrante vs. ciudadano, hombre vs. mujer, dogma vs. humanidad. Su género performativo expone y exacerba los efectos de la violencia cultural, pero también incluye alternativas pacíficas.

Palabras clave: Tiresias; Tiresia; Bonello; género; inmigración; trasnsexualidad; androginia; globalización; mito griego; performatividad.

Sumario: 1. Introduction: "I Tiresias, though blind, throbbing between two lives...". 2. Analysis: The Dispossessed Myth-understood. 3. Conclusion: An Ancient Riddle for the Future?

Cómo citar: Dokou, C. (2017). Gendering Globalized Flows in Bertrand Bonello`s Tiresia. Amaltea. Revista de mitocrítica, 9, 2017, 15-23.

\footnotetext{
1 University Of Athens

cdokou@enl.uoa.gr

https://independent.academia.edu/ChristinaDokou
} 


\section{Introduction: "I Tiresias, though blind, throbbing between two lives..."}

A transsexual named Tiresia, an illegal immigrant from Brazil eking a living in France as a prostitute, is kidnapped and held prisoner by a sociopathic "admirer" of artificial beauty. Deprived of her daily hormone shots, she slowly begins to revert physically to male. Her captor, unable to handle change or intimacy, brutally blinds her, and leaves her to die in the Boulogne forest. Saved by the mute daughter of an old villager, the now mostly-male Tiresia spontaneously develops the gift of prophecy and finds peace helping people with it, in exchange for their hospitality. However, he attracts the jealous attention of the local priest, who happens to be the spitting image of his psycho kidnapper.

In giving his filmic protagonist/s in the above plot the name and attributes of the mythical androgynous prophet, French auteur Bertrand Bonello sets gender conflict as the basis of, or at least the pivotal synecdoche for, the various further conflicts laid out already in his story, thus underlining its tragic existential dimensions. The war of the sexes, according to Simone de Beauvoir in The Second Sex, is the only war that cannot be won by the annihilation or expulsion of the other party: due to the biological imperative for the continuation of the species, which binds us all, "[t]the couple is a fundamental unity which is two halves riveted together, and the cleavage of society along the line of sex is impossible" (de Beauvoir xxv). Moreover, if sex is either negotiated through gender, "a social category imposed upon a sexed body" according to Joan Scott's famous definition (1056), or even organically subsumed by gender interpellations that are, in Judith Butler's view, "performative," "the very apparatus of production whereby the sexes themselves are established" in a "discursive/cultural" way (7), then de Beauvoir's existential irony becomes particularly exacerbated within the social context of the massive and complex cultural upheaval known as globalization. Although hailed by its proponents for enabling a felicitously free movement of goods, ideas and people, "globality," "a social condition characterized by tight global economic, political, cultural, and environmental interconnections and flows that make most of the currently existing borders and boundaries irrelevant" (Steger 9), has destabilized former sustaining structures along with many restrictive ones. For Andy Green and Jan Germen Janmaat, "Globalization, particularly in its recently dominant neo-liberal economic form, involves multiple forces that work to fracture societies and weaken social bonds at the national level, even while it increasingly integrates the global economy" (212).

Additionally, those frictions are more often than not implicated conceptually and materially in formations of gender; as Heike Jensen notes:

...global developments are based on gender as a central formulating feature, from the symbolic and structural to the individual level. At the same time, people's lives and identity formations, both men's and women's, appear to be intricately linked to, and composed within this globalized network of social and cultural transformations. (313)

These transformations have in fact been quite severe on occasion, ranging from savage armed conflicts and "ethnic cleansing" to wars of ideas, classes, cultures, races, economies - the brunt of which has usually been borne by the weaker and most "precariously" placed groups within a society: women, the poor, the illiterate, those 
who are perceived as "different." No wonder that the ancient Greeks placed the overwhelming majority of their sex/gender transformation stories within a (synaesthesiac, perhaps?) context of violence: the Amazons, Caenis/eus, Iphis, Leucippus (Grimal 257), Heracles and Omphale, Atalanta, Achilles. None, however, is as odd as Teiresias, the blind oracle whom we know from the Odyssey (10.487 and 11.84) and the Theban plays of Sophocles and Euripides. Joining the voice of the inscrutable gods to the people's commonsense consensus, Teiresias, whose prophetic powers are organically bound to his having experienced, according to both his genesis myths ${ }^{2}$, life as both man and woman, is presented invariably (and in contrast to other androgynes or army-embedded prophets, like Calchas in the Homeric Cycle) as the peace-bringing voice of moderation and reconciliation in times of cosmic unrest (The Odyssey), civil strife (Oedipus Tyrannus, The Bacchae), or civil war (Antigone). However, when his advice is unheeded, he also heralds an entropic form of doom that always comes true, to the detriment of the House of Cadmus. Interestingly, in most of those cases (and I could argue for all), the conflict is also staged in terms of masculine vs. feminine point of view, with the seer, as noted by critics like Mary Lefkowitz (10) and Stephen Martin (55-57), taking the side of the female, and not only because of the pros and cons of the specific arguments in those stories (see Antigone). Rather, it reflects the archaic idea that both blindness and the seer's job were considered synecdoches of castration, femininity and feminization. In his unique way then, Teiresias is an ongoing study of the ways in which culturally-conditioned sex/gender performativity (as delineated in Judith Butler's Gender Trouble) interacts with situations of conflict within and between cultures in ways that exemplify, but can also question, the seemingly universal binary of the male victimizer-female victim. After all, the androgyny of the ancient prophet falls within the scope of Butler's idea of parodic performativity as a means of resistance to heteronormative strictures:

The notion of gender parody defended here does not assume that there is an original which such parodic identities imitate. Indeed the parody is of the very notion of the original; just as the psychoanalytic notion of gender identification is constituted by a fantasy of a fantasy, the transfiguration of an Other who is always a "figure" in that double sense, so gender parody reveals that the original identity after which gender fashions itself is an imitation without an origin. To be more precise, it is a production which, in effect - that is, in its effect - postures as an imitation. This perpetual displacement constitutes a fluidity of identities that suggests an openness to resignification and recontextualization; parodic proliferation

\footnotetext{
The first comes from a reference to the lost 720BC Pseudo-Hesiodic compliation of seer stories Melampodeia found in Phlegon's Mirabilia c.IV; see also Fragmenta Hesiodea 275. It tells of how Teiresias, hunting in the Cyllene mountains, chanced upon two copulating snakes and struck the male one, whereupon he was transformed into a woman. Years later, he had the same encounter, but struck the female, and was returned to manhood. In an argument between Zeus and Hera on which sex has the greater pleasure during intercourse, Teiresias divulged that a woman has 9/10ths of the pleasure, and was blinded by Hera for gainsaying her. Zeus, however, gave him longevity and prophetic powers as a reward. The second version appears in Callimachus' Hymn V, "On the Bath of Pallas," and details how the young Teiresias chanced upon Athena bathing naked, and the goddess blinded him for his transgression - a punishment which, in classical lore, has a feminizing effect. However, upon the intervention of Teiresias' mother, Chariclo, one of Athena's favorite nymphs, he was compensated with a soothsayer's gift. The myth variants are collected by Philip R. Headings' dissertation "The Tiresias Tradition in Western Literature" (Indiana University 1959), and are also analyzed by Luc Brisson in Le Mythe de Tiresias, Essai d'analyse structurelle (Leiden: E.J. Brill, 1976).
} 
deprives hegemonic culture and its critics of the claim to naturalized or essentialist gender identities. (188)

\section{Analysis: The Dispossessed Myth-understood}

The concept of gender parody as a key to wider social reconditioning informs also the original twist Bertrand Bonello, director of the acclaimed 2001 film The Pornographer, gives the myth in his Palme d'Or-nominated 2003 art film, Tiresia. Bonello's plot follows the myth closely as an ordering and meaning-bearing device, in the way T. S. Eliot envisioned his "mythical method" would work ("Ulysses," 483); at the same time, it tests the myth's fruitful resilience in a context of contemporary interest. Admittedly, the raw content of the film, in line with "the New French Extremity, this recent tendency to the willfully transgressive" of its maker (Quandt 1), along with its glaring artistic faults doomed it commercially: even enthusiastic film critiques couldn't oversee its "constant balancing between the pathetic and the sublime" (Vély - translation from the French mine). Nevertheless, it can serve as an intriguing study on the potential myth-informed deconstruction of our contemporary cultural conflict-lines in the context of a globalized capitalism that is unsettling and inescapable: immigrants vs. citizens, men vs. women, religion vs. natural ethics, normativity vs. oddity, economic oppression and trafficking vs. multiculturalism and the glocal. The film uses content and form to reveal how the performative gender of "Tiresia" exacerbates the effects of cultural globalization flows and gender violence, serving as an activist case-study. Still, at the same time, it slips through the gender trenches towards alternative peaceful intimations of Europe's globalization-informed future. In this way, Bonello joins his individual talent to the rich tradition of Teiresias' successive literary selves, such as, among others, Guillaume Apollinaire's Les Mamelles de Tirésias, T.S. Eliot's The Waste Land, or Yiannis Ritsos's dramatic poetic monologue "Teiresias" in his collection The Fourth Dimension. ${ }^{3}$

Like Teiresias "throbbing between two lives,/ Old man with wrinkled female breasts" in Eliot's The Waste Land (Complete Poems, 43), the structure of the film is cleft in two halves, with Tiresia being played in the first part by a female (Clara Choveaux), in the second by a male Brazilian actor (Thiago Telès), and his opponents in each part, the psycho "poet" Terranova and the priest François, played by the same French actor (Laurent Lucas). The two halves are one, yet not the same. The setting of the story is similarly split: Terranova's house, where he imprisons Tiresia, is an ugly, dilapidated, bare cement structure, with a few graceless pictures on the walls (including one with a twisting snake, symbol of divination and transformation) and chipped kitchenware. Terranova lives alone and has no visitors; even his tiny garden, where he keeps a pet hedgehog that is invariably afraid of him, is choked with weeds and walled up in reinforced concrete, suggesting - prophetically? - the walls thrown up by a phobic Europe against immigrant flows. In contrast, the house of Tiresia and her brother (who functions as her Jungian animus), as well as those of her other

For a detailed overview of the Teiresias figure in the Western literary tradition, please see: William Owen, "Teiresias, A Study in Dramatic Tradition and Innovation," Diss. (Princeton U, 1963); MacInness; and Christina Dokou, "Gendered Oracles: The Teiresian Androgyne in Sophocles, Eliot, Lorca, Ritsos," Diss. (The Pennsylvania State University, 1997. Ann Arbor: UMI, 1998). 
Brazilian transsexual friends, are recalled in her memories as warm, earthy, full of vibrant colors and decorative mementos, the loci of sensuous sexual ménages. The contrast, along with the name Terranova, "New Land," suggests the inhospitable and deceptive nature of the adoptive land. where the foreigner is forced, fleeing or lured away from his/her original home by the forces of globalized flows, to become the pet, the exploited worker, the jailed housewife. One must even literally bleed, besides offering up his/her rich and colorful culture and labor figuratively as the new blood that the old and tired Europe needs pumped into its veins. What leads Terranova to kidnap Tiresia specifically, after all, is a Brazilian children's song he overhears her sing one night in the Bois the Boulogne, and which he later forces her to sing and translate for him, in a travesty of intercultural exchange. The Boulogne forest, where all the foreign prostitutes work, stands between Paris and the country, allowing them contact yet also demarcating the barrier between the foreigner and the Parisian, the transgressor and the exploiter. It is what Gloria Anzaldúa would call a "borderland" or "frontera" zone, a gray no-man's land of conflict, hard negotiations, but also potentially life-generating cultural miscegenation. Like the ancient prophet, who in the plays always stands by the walls of Thebes or outside the palace, serving yet never joining the rulers inside, and, according to Charles Segal, "demonstrates the link between the interior of the house and the cosmic space of sky and underworld" (122), this Tiresia is - like any woman inside patriarchy - close, but never part of the power structures. Finally, in recalling the Arcadian forests of Greek myth, where strange creatures were wont to lurk or frolic, the Bois introduces to the contemporary story the "evergreen" and always relevant nature of myth. At the same time though, observing its darkened and dirtied condition, one is also reminded of the "selva oscura" that precedes Dante's descent to Inferno-a threshold to hell signifying here the outcome of globalized exploitation that, apparently, affects not only the exploited, but also the exploiters' ideas of cultural superiority and purity.

Terranova in his obsession calls transsexuals "roses with thorns," for two reasons: like cultivated roses, transsexuals are artificial and therefore satisfy his twisted sense of perfectionist aestheticism; alternatively, unlike immigrants, roses have "no past," which he considers "vulgar." The rose symbol recalls Dante's vision of heavenly order in La Divina Commedia, but the Western paradise the sociopath offers is false, dead, and more like Inferno or Purgatorio. As Bonello notes in an interview, "For Terranova, Tiresia represents an idea of perfection. Better than a man, better than a woman. His fascination is intellectual, philosophical and aesthetic" (Rachael Scott). We see him in a museum gazing at the classical statues of Hermaphroditus and the gods: he has less trouble with them as representatives of a past, fixed, and static cultural heritage than with real humans with real bodies, pains, needs. This could be viewed as a wider comment on the uses of myth in contemporary society, not as something dusty to be placed inside a glass case or pedestal and venerated from afar, but as something to be felt and experienced organically, even when it unsettles by revealing dimensions alien to us. Instead, when Tiresia screams in despair to let her go, Terranova leaves the house for days and gets drunk not to hear her; when, at the end, she offers him her love and fidelity, in exchange of a proper home she, like all immigrants, tries to make out of her hardships, he betrays and blinds her, subjecting her to what is, according to the ancient myth's semantics, "a cultural sublimation of castration" (MacInnes 76). One might even read into Tiresia's submission and betrayal a possible sly comment by Bonello that the eventual cultural assimilation 
of exploited immigrants is a version of the Stockholm syndrome, and can have no happy ending as such. Terranova is a voyeur, and sexually impotent, "pruned" by his dusty culture like the roses he loves, and therefore the opposite of Teiresias and Tiresia, who've had experience of love as both male and female, and whose blindness (or marginality) allow them a deeper understanding into the best and the worst of the human soul. Terranova, like the privileged European he is, thinks of himself as a god, aloof and artistic, needing no one, despising the natural and the frail in the form of "the poor, the huddled" bodies "yearning to be free," yet washed up by the globalized forces of Ananke, a force stronger than even the gods, at the walls of his house. No wonder he, along with Zeus and Hera in the first version of the Teiresias myth, first kidnap a human to teach them about love, then punish him when they discovers in him "extra" aspects they can't handle.

The key scene where Tiresia, forced to wash naked in front of Terranova, first tries to disgust him by demonstrating her penis, then turns shy under his unblinking gaze and begs for privacy, is in a sense a reversed reenactment of the second version of the Teiresias myth, where he unwillingly trades eyesight for insight when chancing upon a naked bathing Athena, the androgynous goddess of wisdom. Terranova sees the naked truth about Tiresia: that in her "superfluous" bodily signification she is neither an abomination, as the dominant bourgeois culture would label the transsexual, the sex worker, the illegal immigrant, nor the house ornament Terranova fantasizes about, but an autonomous human being with feelings. Nevertheless, he is tragically blinded by his systematic refusal to understand this. He, the dominant element in the gender and globalization game, is blinder than the blind, deafer than the deaf, dimmer than the dim-exactly what Teiresias calls the "clever" Oedipus Tyrannus when the latter mocks him (Sophocles, Oedipus Tyrannus 1.371).

The irony is apparent in the event that marks the turning point between the two halves of the film, when Terranova blinds Tiresia, who has been reverting to male without her hormone treatments. He has first killed the hedgehog, too, recalling the first version of the myth, where Teiresias changes into a woman because he chanced upon two snakes copulating and struck the male one. Terranova abandons her in the Bois for dead, but this is only the beginning of a new life for Tiresia. Her resurrection of sorts that inaugurates the second part of the film must not be considered forced, as it ties in to the archetypal myth that has the power of eternal return, and more specifically alludes to the original Teiresias' divinely-prolonged lifespan. This half is set in a small rural community, a kind of agrarian "Arcadia" where the hunted, mutilated suppliant will finally find the hospitable haven towards which all immigrants strive. It is notable that the girl who rescues him (Tiresia is now male, and played by one) and falls in love with him is mute, serving as his anima now, while her aged father is of foreign descent (probably a gypsy). Again, it is the minority, the marginal and the dispossessed who are the richest in compassion and wisdom, who first ask the stranger his name (so that the audience learns it, acknowledging at last a subjectivity long denied by Terranova) and offer hope of integration in the host culture. As Edward Said has noted, the intellectual gift is sharpened with the experience of exile, or exile is what every intellectual feels, even at home, since their offbeat insightful perspective also damns them as perpetual misfits (47-50). In that sense Tiresia's spontaneous new gift of prophecy in the film, a magic realist element, can be seen as a metaphor for the experience of foreignness, femininity, and human darkness he carries now. Similarly, the girl and wise old father, who is said to be always "on 
the road" and disappears in the end into a dark grove, are set up as a kind of blind old Oedipus Coloneus and Antigone, the daughter "born to join not in hatred, but in love" (Sophocles, Antigone 1.523), suggesting a community of the "blind" who are, however, truly blessed. As the old man says, "if you have a gift, you have to give"and not, like Terranova, hoard and destroy.

Terranova's double in this part is another man made impotent by cultural constraints, father François, the local priest, whose name also recalls France, the troublesome host country of Tiresia. He also has a fetish for roses (real ones), and is also a "hypocrite lecteur, mon semblamble, mon frère" (to use T. S. Eliot's condemnation in The Waste Land, 39), preaching but not believing. In him we see another way in which ancient myth has degenerated in a modern globalized context, that is, in becoming dead letter and rigid dogma instead of a lived, inspirational reality guide. One wonders at this point why Bonello chose the same actor to play both roles: some viewers might think the priest is living a double life as a psycho. However, I believe the intention is rather to show through this visual metaphor the duplicity of the hegemonic host culture, whose institutions of power and control include the church, the art world, and global capital. Alarmed by the loss of his flock-who now flock to Tiresia's house to benefit from his prophetic visions and offer him simple homegrown gifts of food, wine and clothes in return, in a parodic performance of "globalized" economic exchanges-father François confronts Tiresia and is convinced of his seer's gift. Furthermore, his attempts to subjugate this Other culturally by making him cower before his dogma, or objectifying him as another piece of art he can control, fail. It should be noted that, ironically, both the Montigliani painting to which father François compares Tiresia and the Omar Khayyam poem he reads to Tiresia so as to invoke in him respect for the mysterious ways of God are foreign pieces. Yet Tiresia, in his newfound wisdom, will not be bated by Eurocentric and colonialist displays of cultural superiority, facing them with the humble yet dignified insistence that he is just a body with human frailty and needs, "just a whore from Brazil." With a simplicity and immediacy that transcends cultural barriers and contrasts with the priest's hegemonic stance, Tiresia declares himself grateful to have been "taken in" and away from his troubles, happy to offer back-he repeatedly uses the transculturally loaded world "translate" - all he can, in a paradigm of glocal economy. Again, we see not only the clash of gendered bodies that subvert clear-cut sex/gender lines since, ironically, they are both brothers in artificiality (the culturally-neutered male priest and the fully-functional transsexual), but also the clash of cultures, classes, languages and mentalities global dislocation has engendered. This time, though, Tiresia has the advantage of esoteric knowledge, and peace, while it is the host culture that feels intruded upon and alarmed and tries to browbeat the newcomer. Some, like Yiannick Vély, admittedly would see the ending, when the priest runs Tiresia over with his car and kills him, as a triumph of brutal violence with which intransigent nationalistic and racist forces deal with incoming migrants: "[c] reature of the night, without sex or nationality, Tiresia finally finds neither repose for her soul, or her place in the world of the living. Her miraculous gift of prophecy is perceived as a malediction, a conspicuous sign supplementing her bizarre deformity and her profound difference." However, my reading is one of evident hope, for in the very next scene we see the priest repentant, lovingly helping to raise the child the mute Anna has got of Tiresia, under the sounds of Tiresia's Brazilian lullaby. Thus in an organic, sense- and body-oriented way, the "spiritual" man accepts that the 
immigrant body and mind, creative and procreative, with all his/her Otherness and mystery, is here to stay, not as a marginal, but as a member of a larger, more robust, if less conventional, family. Like Teiresias' two bodies melding into something greater than the sum of its parts, French sterility and nationalist isolationism give way to a miscegenated, hybrid generation. This is the true gift of the globalizing wave which, like the benedictions of the Olympians sometimes, comes forced upon the human subject, and with mixed emotions - but come it will: "The union of opposites creates here marvel, beauty and monstrosity, sacredness and profanity, profundity and surface. At the risk of pomposity sometimes, Bonello glorifies a body insolent in its innocence and its interior earthquakes" (Morice). In this way, the particular mythic message about flow and change harmonizes with the wider context of myth revision that acknowledges and utilizes myth's diachronic flexibility. The result enables what Martine Beugnet identifies as Bonello's aesthetic commitment to the "cinema of sensation" (174) putting emphasis on the bodily senses, "where the audio-visual force of the cinematic work tends to be given precedence over plot, dialogue and conventional narrative progression, and as such, pre-empts and determines the function assigned to the medium as a narrative and representational construct, or as the articulation of an ideological discourse" (175). Here it is not just film that claims a feeling body, but myth as well: Beugnet's linking of the aesthetic of sensation to " $[\mathrm{t}]$ he opening shots of Tiresia" with the "live mass of magma" exploding and twisting to Beethoven's seventh symphony (175), expresses not just Teiresias' endless metamorphoses (in myth, fiction and art) but "the materiality of the medium of the moving image, film's inherent process of endless becoming" (176). Thus the director's montage-warped vision establishes from the very beginning this miscegenation of the Dionysian archetypal with the Apollonian in film and cultural archaeology.

\section{Conclusion: An Ancient Riddle for the Future?}

Bonello's ending leaves way too many threads dangling and questions unanswered, but, after all, the future of the dispossessed, the feminized of the earth, in the never-ending global cultural and economic upheavals is ever uncertain. As Tony McKibbin observes about Tiresia, "The film utilizes myth not to say how we must behave, but to illustrate that apparently very contemporary problems have a layered existence that can help us today, can help us how to live. It's through exploring this underpinning we can make sense of the world." At the same time, the film's fragmentary nature, musical interventions and strange artistic imagery serve, as Bernard Stiegler notes, as a re-training of our senses and consciousness, which have been blinded by the onslaught of commercialized images and nationalistic racist agendas, so that we may again see the hidden truths of human life, anywhere on the planet. Bonello's aestheticism, in other words, follows the Teiresian gender-bending paradigm in the matter of form as well, blending creatively together the mythic universe with its paradoxes and archetypes, its quest cycles and eternal returns, with the medium of film, whose flowing images counteract the fixity of "museum-oriented" approaches to Europe's classical past. 


\section{Works cited}

Anzaldúa, Glora, (1987) Borderlands/La Frontera: The New Mestiza. $2^{\text {nd }}$ ed. San Francisco: Aunt Lute Books, 1999. Print.

De Beauvoir, Simone. (1949) The Second Sex. Trans. H. M. Parshley, with an introduction by Deirdre Bair. New York: Vintage, 1989. Print.

Butler, Judith. Gender Trouble: Feminism and the Subversion of Identity. New York: Routledge, 1990. Print.

Eliot, T.S. The Complete Poems and Plays, 1909-1950. San Diego and New York: Harcourt Brace Jovanovich, 1980. Print.

---. "Ulysses, Order, and Myth.” The Dial 75(1923): 480-483. Print.

Green, Andy, and Jan Germen Janmaat. Regimes of Social Cohesion: Societies and the Crisis of Globalization. Hampshire: Palgrave MacMillan, 2014. Print.

Grimal, Pierre. The Dictionary of Classical Mythology. Trans. A. R. Maxwell-Hyslop. New York: Blackwell, 1986. Print.

Jensen, Heike. "Pagkosmiopoiisi."Fylo@Erevna. Ed. Ntina Vaiou and Maria Stratigaki. Athens: Metaihmio, 2010. 311-343.

Lefkowitz, Mary R. Women in Greek Myth. Baltimore: Johns Hopkins UP, 1986. Print.

MacInnes, Deborah. "Prophecy and Persuasion: Tiresias in Greek Tragedy." Diss. Duke U, 1995. Print.

Martin, Stephen H. “A Comparative Study of Androgyny in Twentieth-Century Experimental Literature." DAI 45:2 (1984): 517A. The New York U. Print.

McKibbin, Tony. "Film Notes." Tiresia DVD package. London: Tartan Films/Tartan Video, 2005. Print.

Morice, Jacques. "Tiresia: Critique lors de la sortie en sale de 15/10/2003." Télérama.fr. 2015. Web. 9 November 2016. http://www.telerama.fr/cinema/films/tiresia,129509.php

Quandt, James. "Flesh \& Blood: Sex and violence in recent French cinema." Artforum. February 2004. Web. 26 Jun, 2012. https://www.artforum.com/inprint/issue=200402\&id=6199

Said, Edward. Representation of the Intellectual. NY: Pantheon Books, 1994. Print.

Scott, Joan W. "Gender: A Useful Category of Historical Analysis." The American Historical Review 91.5 (1986): 1053-1075. Print.

Scott, Rachael. "Entertainment: Film \& TV: Interviews: Bertrand Bonello." gaydarnation. com. 14 July 2005. PDF. 28 June 2012. https://www.google.gr/?gfe_rd=cr\&ei=TlIkWIbrIK3s8wfVi6qQBg\&gws_rd=ssl\#q=Bonello+gaydarnation.com

Segal, Charles. Sophocles'Tragic World: Divinity, Nature, Society. Cambridge: Harvard UP, 1981. Print.

Sophocles. The Plays and Fragments of Sophocles. Ed. and trans. sir Richard Jebb. Cambridge: Cambridge UP, c.1883. Print.

Steger, Manfred B. Globalization: A Very Short Introduction. Oxford: Oxford University Press, 2013. Print.

Stiegler, Bernard. "Tirésias et la guerre du temps: Autour d'un film de Bertrand Bonello." De la misère symbolique: Tome 1. L'époque hyperindustrielle. Paris: Galilée, 2004. 163-185. Print.

Tiresia. Dir. Bertrand Bonello. Perf. Laurent Lucas, Clara Choveaux, Thiago Teles, Celia Catalifo, and Lou Castel. Haut et Court, 2003. Released by Tartan Films/Tartan Video, 2005. Film.

Vély, Yannick. “Tiresia.” FilmdeCulte. 2011. Web. 9 November 2016. http://www.filmdeculte.com/cinema/film/Tiresia-686.html 